\title{
Comparative Surveillance of Parasitic Infestation in Channa punctatus (Osteichthys: Channidae) Collected from Open and Closed Water in Sylhet, Bangladesh
}

\author{
Md. Faruque Miah ${ }^{1, *}$, Mitu Deb ${ }^{1}$, Hazrat Ali ${ }^{1}$, M. M. A. Quddus ${ }^{2}$, Kawser Ahmed $^{3}$ \\ ${ }^{1}$ Department of Genetic Engineering and Biotechnology, Shahjalal University of Science and Technology, Sylhet, Bangladesh \\ ${ }^{2}$ Department of Zoology, University of Dhaka, Bangladesh \\ ${ }^{3}$ Department of Oceanography, University of Dhaka, Bangladesh \\ *Corresponding Author: faruque-btc@sust.edu
}

Copyright $@ 2013$ Horizon Research Publishing All rights reserved.

\begin{abstract}
This study deals with the investigation of parasitic infection in Channa punctatus collected from open and closed water in Sylhet, Bangladesh. Skins, gills and intestine of the host were observed for finding parasites. In total 253 parasites were identified under 26 species from 40 experimental fish. 12 species of ectoparasites and 13 species of endoparasites were recorded with 1 more species of both ecto and endo parasitic activities in Channa punctatus. Different types of parasites such as protozoa, platyhelminth, nematoda, acanthocephala, arthropoda, gastrotricha and rotifer were found from experimental fish. The overall incidence of infection in Channa punctatus was higher $(60.00 \%)$ of protozoan parasites. The highest incidence of infection of protozoan parasites was recorded as $60.00 \%$ in open water samples. On the other hand, the highest incidence of infection in closed water was recorded as $75 \%$ of platyhelminth parasites. Furthermore, the intensity of infection by protozoan species was recorded in open and closed water fish as 2.92 and 4.83 respectively while the intensity of infection by platyhelminthes species found was 1.00 and 1.87 in open and closed water respectively. Finally, two new species (Rotifer $s p$. and Chaetonotus sp.) were assumed to be new parasites in Channa punctatus.
\end{abstract}

Keywords Surveillance, Infestation, Channa punctatus, Open water, Closed water

\section{Introduction}

The snake headed fish Channa punctatus is the representative of the Channiform family Channidae which is the most important species of inland fisheries of Bangladesh. Among other snake headed fishes (C. striatus, C. marulius, C. barca, and C. orientalis) Channa punctatus is one of the most popular fish with delicious taste. This fish is mostly served as a curry dish of boiled fish kneaded to soft moist mass mixed with spices or dry in form. It is mud-loving fish and due to its food habit, it can act as an intermediate host for many helminth parasites. However, this fish has a very good commercial value in Bangladesh as well as in Indian subcontinent.

Parasitic infestation has harmful influence for fish health that inhibits the normal growth of the fishes and outbreaks high mortalities. The declination of Channa punctatus is regarded as its susceptibility to Epizootic Ulcerative Syndrome disease [1] and over exploitation and habitat degradation [2]. Air breathing Channa punctatus can live without water for long time without using any preservatives, this fish increasingly being used for freshwater aquaculture in Bangladesh to diverse favorable cultural characteristics. But the effects of parasites are one of the factors hindering high production of fish [3]. Also, the parasitic infections of this experimental fish results in economic losses due to not only mortality, but also treatment costs, decreasing growth that reduces the expansion of aquaculture.

Enhanced concern in fish culture showed consciousness of parasites that infest fish health, growth and survival. In Bangladesh parasitic study has been conducted in both freshwater and marine environment where several protozoan, helminthes and crustacean parasites were recorded in different fish species. Some studies of Channa punctatus fish have been done in biology, mainly in the breeding program of this fish [4], and histopathology of diseased fish [5,6]. Helminth parasites in Channa striatus and Channa marulius have also been listed in [7,8]. Infestation of helminth parasites and histopathological changes in snake headed fishes is reported in [9]. Incidence of endo-parasites of two snake headed fish Channa striatus and Channa marulius was studied in [10]. The morphology of Genarchopsis dasus parasites infesting Channa punctatus is described by [11] and seven parasitic species as well as Genarchopsis bangladeshensis of Channa punctatus was identified in Bangladesh where fishes were collected from hatchery and sewage lagoon [12]. 
Study of parasites is scant in Bangladesh, and a little knowledge about the distribution, prevalence, parasitic intensity, pathogenic effects and control of most of the diseases in natural population of freshwater fish has been studied particularly in Sylhet region of Bangladesh. As the Channa punctatus is most popular fish in Sylhet as well as throughout the country, their abundance is reducing due to over exploitation, environmental stress and the occurrence diseases. Though a lot of fish species are available in the water body of Sylhet very little parasitic investigation has been done so far. As a consequence, parasitic infestation has been provoked in fisheries stock over the time. Therefore, it is a great demand to study fish parasites in the water body of Sylhet.

Large number of water bodies around the Sylhet division promotes the region as one of the major sources of fish producing area in Bangladesh. The present work was undertaken to investigate the different parasite communities, and to find out the prevalence and intensity of infestation in Channa punctatus with different habitat of varying water quality in Sylhet.

\section{Materials and Methods}

\subsection{Study Location and Sampling}

A total of 40 individuals of Channa punctatus were collected randomly from both closed (20 fish) and open water (20 fish) at different times from different locations of Sylhet, during the period of August to November, 2011. Collected fish samples were transferred to the Animal Biotechnology Laboratory (ABL) of the Department of Genetic Engineering and Biotechnology (GEB), Shahjalal University of Science and Technology (SUST), Sylhet, Bangladesh.

\subsection{Experimental Procedure}

Fish samples were taken in live condition, killed by hand and examined immediately for parasitological study using compound microscope. A clean spatula was held to the body of each individual and it was drawn backwards towards the tail in a smooth movement and lifting off a small amount of mucous from the different sites of the body for investigating parasites from skin. Later on, for each sites, mucous scrapings placed on a clean glass slides and examined under the $4 \mathrm{x}, 10 \mathrm{x}$ and $40 \mathrm{x}$ lenses of the compound microscope for observing the presence of parasites. In gill biopsy, a fine pair of scissors was used to cut open the operculum from both sides to reveal the opercular cavity. Gill filaments were taken out by cutting off the two ends of the gill arches, and kept on petridishes with the saline solution of $\mathrm{NaCl}(70 \%)$. Furthermore, small sample of gills was made by splitting up gill filaments using fine scissors and observed under microscope. Each fish was dissected with a fine scissors used to make an incision along the mid-ventral line of the body to find out the parasites from the internal organs. All other organs (stomach, heart, liver, kidney, spleen and gall bladder) were shredded by using forceps and needles, and separated from intestine. The intestines were carefully opened out by an incision from the body and put into a petridishes with the physiological saline solution ( $\mathrm{NaCl} 70 \%)$. Sometimes larger nematodes (roundworms) were visible in naked-eyes lying in the body cavity with their heads buried in the intestines and were quickly isolated using forceps, fixed on glass slide with glycerin. Saline solution of the intestine was made by scrapping of the epithelial tissues using fine scissors onto petridishes and viewed under several microscopic lenses. All the isolated parasites were fixed in glass slides with glycerin.

Some parasites are virtually transparent, smaller in size and unable to move in saline solution of target organs. In that case, we had to scan slowly by adjusting the microscope condenser power higher to lower. And viewed the saline solution under dark-filed to identify parasites present in the target organs. Microscopic picture of all the isolated parasites were taken by converted microscope as well as high megapixel camera and the parasites were identified by the image analysis [13-17].

\subsection{Analysis of Parasitic Infestation}

The analysis of parasitic infestation for finding the incidence, intensity, density and index were carried out by following formulae [18]:

$$
\text { Incidence of infection }=\frac{\text { Infected host } \times 100}{\text { Total host examined }}
$$

Intensity of infection

$$
=\frac{\text { No. of parasites collected in a sample }}{\text { No. of infected host }}
$$

Density of infection

$$
=\frac{\text { No. of parasites collected in a sample }}{\text { Total host examined }}
$$

Index of infection

$=\frac{\text { No. of host infected } \times \text { No. of parasites collected }}{\text { Total host examined }}$

\section{Results}

\subsection{Identification of Parasites}

In this experiment total 253 parasites representing 23 species and 3 unidentified species were collected from the host fish. Out of 26 parasites the twelve ectoparasites and thirteen endoparasites were observed whereas one species showed both ecto- and endo-parasitic activities (Table 1).

Five protozoan parasites such as Trichodina $s p$., Chilodonella sp., Chilodonella sp. (cysts) and Ichthyobodo $s p$. Actinophrys $s p$. were identified from the gills and skin of the infected fishes but one species of parasite was remainunidentified. Trichodina is a common freshwater protozoan parasites found in all experimental fishes. Alive 
Chilodonella is elongated heart shaped but when in dead condition it was found as a round form full of tiny bubbles inside with thin band of dark pigment in middle. Ichthyobodo $s p$. is very small but fast moving protozoa were found both gills and skin of the infected fishes.

Monogenean Gyrodactylus sp. was found from the body surface of the infected fishes whereas digenian gill flukes Dactylogyrus $s p$. was also found from the gills of the examined fishes. Metacercariae hemiuridae was recovered from the intestine and encysted Metacercariae $s p$. cyst was observed from both gills and intestine. The larva of Metacercariae inside the cyst was actively moving and Metacercariae was contained in orange capsules mixed with a thin band of dark pigment. The Apophallus sp. was isolated from the skin of the infected fish. Trematode Allocreadium $s p$. and Macrolecithus sp. both were found in the intestine of the infected fish while one of the isolated platyhelminth parasite was found in both gills and skin remain unidentified. Some nematode parasites such as Procamallanus sp., larvae of Procamallanus sp., Camallanus sp. and round worm Pratylenchus $s p$. were isolated and identified. In microscopic analysis nematode eggs of Rhabdochona sp. and Ascaridia $s p$. were seen in the intestine of Channa punctatus. The parasitic acanthocephalan such as Pallisentis sp., Leptorhynchoides sp. and eggs of Acanthocephalan sp. were present in the intestine of the observed fish.

Table 1. Parasitocoenosis of Channa punctatus in Sylhet, Bangladesh

\begin{tabular}{|c|c|c|c|c|c|c|c|}
\hline Parasite groups & Parasite species & Site of infestation & $\begin{array}{c}\text { Infected } \\
\text { fish }\end{array}$ & $\begin{array}{l}\text { C/W } \\
\text { fish }\end{array}$ & $\begin{array}{l}\mathrm{O} / \mathrm{W} \\
\text { fish }\end{array}$ & $\begin{array}{c}\text { No. of } \\
\text { Parasite }\end{array}$ & $\begin{array}{l}\text { Incidence of } \\
\text { infection (\%) }\end{array}$ \\
\hline \multirow{6}{*}{ Protozoa } & Trichodina sp. & Gills, Skin & 13 & 8 & 5 & 53 & 32.50 \\
\hline & Chilodonella sp. & Skin & 2 & 2 & 0 & 9 & 5.00 \\
\hline & Chilodonella sp. (cysts) & Skin & 1 & 1 & 0 & 11 & 2.50 \\
\hline & Ichthyobodo sp. & Gills, Skin & 6 & 0 & 6 & 15 & 15.00 \\
\hline & Actinophrys $s p$. & Gills & 1 & 1 & 0 & 1 & 2.50 \\
\hline & Unidentified Protozoan & Gills & 1 & 0 & 1 & 4 & 2.50 \\
\hline \multirow{8}{*}{ Platyhelminth } & Dactylogyrus sp. & Gills & 6 & 6 & 0 & 10 & 15.00 \\
\hline & Gyrodactylus sp. & Skin & 3 & 1 & 2 & 3 & 7.50 \\
\hline & Metacercariae sp. (cysts) & Gills, Intestine & 4 & 4 & 0 & 10 & 10.00 \\
\hline & Metacercariae hemiuridae & Intestine & 1 & 1 & 0 & 1 & 2.50 \\
\hline & Allocreadium sp. & Intestine & 1 & 0 & 1 & 1 & 2.50 \\
\hline & Macrolecithus sp. & Intestine & 1 & 0 & 1 & 1 & 2.50 \\
\hline & Apophallus sp. & Skin & 1 & 1 & 0 & 3 & 2.50 \\
\hline & Unidentified Platyhelminth & Gills, Skin & 2 & 2 & 0 & 3 & 5.00 \\
\hline \multirow{7}{*}{ Nematoda } & Round worm & Intestine & 4 & 3 & 1 & 7 & 10.00 \\
\hline & Pratylenchus sp. & Intestine & 1 & 0 & 1 & 1 & 2.50 \\
\hline & Camallanus sp. & Intestine & 1 & 1 & 0 & 1 & 2.50 \\
\hline & Procamallanus sp. & Intestine & 1 & 1 & 0 & 1 & 2.50 \\
\hline & Procamallanus sp. & Intestine & 1 & 1 & 0 & 1 & 2.50 \\
\hline & Rhabdochona sp. (eggs) & Intestine & 1 & 1 & 0 & 2 & 2.50 \\
\hline & Ascaridia sp. (eggs) & Intestine & 1 & 0 & 1 & 2 & 2.50 \\
\hline \multirow{3}{*}{ Acanthocephala } & Pallisentis sp. & Intestine & 1 & 1 & 0 & 1 & 2.50 \\
\hline & Leptorhynchoides sp. & Intestine & 1 & 1 & 0 & 1 & 2.50 \\
\hline & Acanthocephalan sp. (eggs) & Intestine & 1 & 1 & 0 & 2 & 2.50 \\
\hline \multirow{2}{*}{ Arthropods } & Lernaea sp. & Skin & 1 & 1 & 0 & 1 & 2.50 \\
\hline & Unidentified Arthropod & Gills, Skin & 4 & 3 & 1 & 4 & 10.00 \\
\hline Gastrotrics & Chaetonotus sp. & Gills & 1 & 1 & 0 & 1 & 2.50 \\
\hline Rotifera & Rotifer $s p$. & $\begin{array}{l}\text { Gills, Skin, } \\
\text { Intestine }\end{array}$ & 12 & 1 & 11 & 103 & 30.00 \\
\hline
\end{tabular}


The anchor worm Lernea sp. and an unidentified arthropod were noticed in the skin of the examined fish. Gastrotrich was also reported as parasitic influences in fish species and Chaetonotus sp. was determined in gills of experimental Channa punctatus. A small number of species of phylum rotifera has been considered as parasites of fish. One of the unidentified rotifer species was found in the intestine, gills and skin of this experimental fish and that species was recorded highest number of this study. Though it was not recognized as a parasite but it is assumed (Table 1).

\subsection{Parasitic Infestation}

The analysis for finding the incidence (Table 2), intensity, density and index were carried out. During the study period, the highest number of rotifer species (103) and lowest (1) of Chaetonotus sp. of group gastrotricha were collected from the infected fish. The highest incidence $(60.00 \%)$ and index (55.80) rate were found in case of protozoan parasites whereas highest intensity (8.58) and density (2.58) goes to rotifer species in Channa punctatus. Gastrotrich parasites showing the lowest value for incidence $(2.50 \%)$, intensity (1.00), density (0.03) and index (0.03) in Channa punctatus, however, intensity of arthropod was the same as gastrotrich which was also 1.00 (Table 2)

In this study, the incidence of different parasite groups were recorded from both sampling spots (Figure 1 and 2). The incidence of parasite in closed water group was found higher than that of the open water group. Furthermore, the intensity of parasite groups in Channa punctatus were also calculated and highest intensity of infection was recorded as 9.27 in open water for rotifer while in closed water the highest intensity of infection was recorded 4.83 for protozoan parasites (Table 3 ). Lowest intensity of infection was recorded zero (0) for acanthocephalan and gastrotrich parasites in both ecosystems (Table 3).

Table 2. The fluctuations of overall incidence (\%), intensity, density and index of parasites in Channa punctatus

\begin{tabular}{|c|c|c|c|c|c|c|c|}
\hline Parasite groups & $\begin{array}{c}\text { No. of } \\
\text { examined fish }\end{array}$ & $\begin{array}{c}\text { No. of } \\
\text { infected host }\end{array}$ & $\begin{array}{c}\text { No. of } \\
\text { collected } \\
\text { parasites }\end{array}$ & Incidence (\%) & Intensity & Density & Index \\
\hline Protozoa & 40 & 24 & 93 & 60.00 & 3.88 & 2.33 & 55.80 \\
\hline Platyhelminth & 40 & 19 & 32 & 47.50 & 1.68 & 0.80 & 0.38 \\
\hline Nematoda & 40 & 10 & 15 & 25.00 & 1.50 & 3.75 \\
\hline Acanthocephala & 40 & 03 & 4 & 7.50 & 1.33 & 0.10 & 0.30 \\
\hline Arthropoda & 40 & 5 & 5 & 12.50 & 1.00 & 0.13 & 0.63 \\
\hline Gastrotricha & 40 & 1 & 1 & 2.50 & 1.00 & 0.03 & 0.03 \\
\hline Rotifera & 40 & 12 & 103 & 30.00 & 8.58 & 2.58 & 30.90 \\
\hline
\end{tabular}

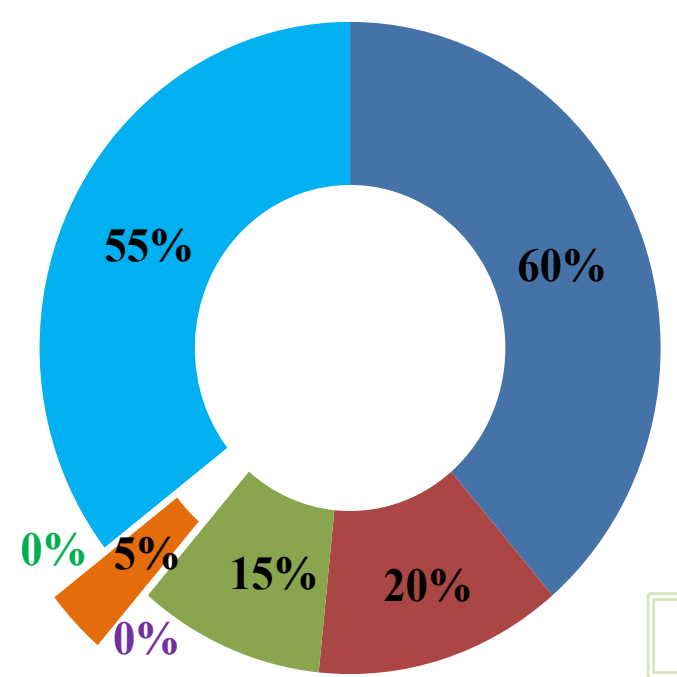

Total observed 20 fishes

\begin{tabular}{|l|}
\hline Protozoa \\
Platyhelminth \\
Nematoda \\
Acanthocephala \\
Arthropoda \\
Gastrotricha \\
Rotifera \\
\hline
\end{tabular}

*Acanthocephala and Gastrotricha $=0 \%$

Figure 1. The incidence of different parasite groups of Channa punctatus collected from open water 


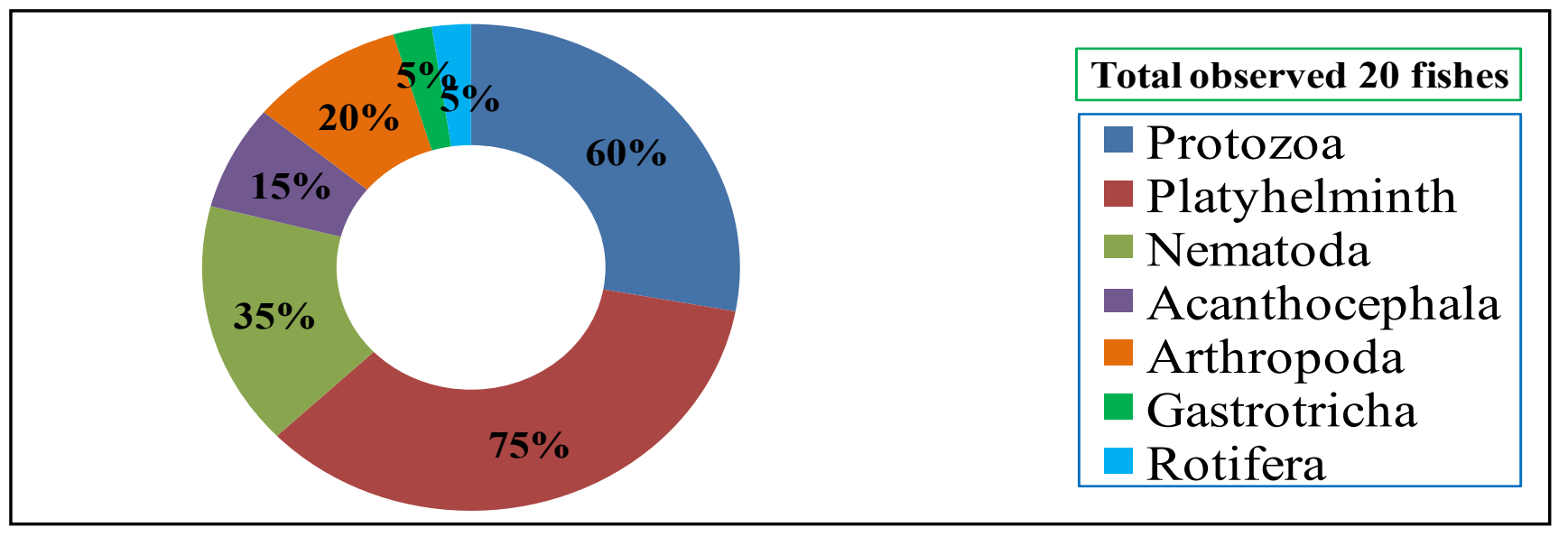

Figure 2. The incidence of different parasite groups of Channa punctatus collected from closed water

Table 3. Intensity of parasite groups in Channa punctatus collected from open and closed water

\begin{tabular}{|c|c|c|c|c|c|c|c|c|}
\hline \multirow{2}{*}{ Parasite groups } & \multicolumn{2}{|c|}{ No. of examined fish } & \multicolumn{2}{|c|}{ No. of infected host } & \multicolumn{2}{|c|}{ No. of collected parasites } & \multicolumn{2}{|c|}{ Intensity of infection } \\
\hline & Open water & $\begin{array}{c}\text { Closed } \\
\text { water }\end{array}$ & Open water & $\begin{array}{c}\text { Closed } \\
\text { water }\end{array}$ & Open water & $\begin{array}{c}\text { Closed } \\
\text { water }\end{array}$ & Open water & $\begin{array}{c}\text { Closed } \\
\text { water }\end{array}$ \\
\hline Protozoa & 20 & 20 & 12 & 12 & 35 & 58 & 2.92 & 4.83 \\
\hline Platyhelminth & 20 & 20 & 4 & 15 & 4 & 28 & 1.00 & 1.87 \\
\hline Nematoda & 20 & 20 & 3 & 7 & 5 & 10 & 1.67 & 1.43 \\
\hline Acanthocephala & 20 & 20 & 0 & 3 & 0 & 4 & 0 & 1.33 \\
\hline Arthropoda & 20 & 20 & 1 & 4 & 1 & 4 & 1.00 & 1.00 \\
\hline Gastrotricha & 20 & 20 & 0 & 1 & 0 & 1 & 0 & 1.00 \\
\hline Rotifera & 20 & 20 & 11 & 1 & 102 & 1 & 9.27 & 1.00 \\
\hline
\end{tabular}

\section{Discussion}

\subsection{The Parasites Population Makeup}

In this experiment the protozoan species such as Trichodina sp., Ichthyobodo sp., and unidentified protozoan were identified from open water fish and Trichodina sp., Chilodonella sp. Actinophrys $s p$. were found in closed water fish. Platyhelminth parasites such as Gyrodactylus sp., Allocreadium sp., and Macrolecithus sp. were recorded in open water and Dactylogyrus sp., Gyrodactylus sp., two Metacercariae spp., Apophallus sp., and unidentified platyhelminthes were observed in closed water fish. Nematodes (round worm sp., Pratylenchus sp., Ascaridia sp. eggs) were isolated from open water fish and round worm $s p$. Camallanus sp., Procamallanus sp. and Rhabdochona sp. eggs were found in closed water fish. Acanthocephalan (Pallisentis sp., Leptorhynchoides sp., Acanthocephalan sp. eggs) was found only in closed water fish. Lernaea sp. was isolated from closed water fish. Gastrotrich species (Chaetonotus sp.) was found only in one fish of closed water. Rotifer $s p$. was found mainly in open water but it was also observed in closed water fish. Chaetonotus $s p$. and rotifer $s p$. are new parasite recorded for Channa punctatus during this investigation. Rotifer $s p$. was collected in high numbers (103) and found in all target organs where low numbers (1) of Chaetonotus sp. was found only in gills (Table 1).

\subsection{Contrast between Sampling Sites}

The comparison of the micro parasite communities between open and closed water is fairly high. Protozoans are common freshwater parasites and in this study, the incidence of protozoan parasites at different sampling sites was found alike $(60 \%)$. In case of helminthes, higher incidence was found $75 \%$ in closed water while only $20 \%$ in open water Channa punctatus. A difference in incidence of platyhelminthes between the sampling sites is high due to poor local level of environmental sanitation in closed water. Considerately nematodes were also found most $(35 \%)$ in closed water and less (15\%) in open water. Incidence of arthropods in water bodies were found 5\% in open water and $20 \%$ in closed water. Parasitic acanthocephalan was not found in open water during this investigation and their only incidence in closed water was $15 \%$. The incidence of gastrotrichs was $5 \%$ only in closed water. Rotifers comprises 
high incidence $(55 \%)$ in open water and low $(5 \%)$ in closed water (Figure 1 and 2).

\subsection{Comparison with Other Parasitic Study in Channa punctatus}

It was observed that Encredium dacci, Camallanus adamsia, Camallanus ophicephali, Pallisentis sp. were located in the intestine and Genarchopsis sp. in the stomach of Channa marulius, Channa striatus, Channa punctatus, Channa gachua $[19,20]$. Research shows that A few nematodes were observed in the body cavity of different snake headed fish and all helminthes except Genarchopsis sp. in the middle region and posterior region of the intestine [9]. In this investigation, it was found that nematode Camallanus sp. and acanthocephalan Pallisentis sp. from the intestine of Channa punctatus resembling to this study as shown in Table 1.

The data recorded that Channa punctatus was infected by seven species of parasites where four trematodes (Genarchopsis bangladensis, Allogomtiotrema attu, Phyllodistomum sp., Neopecoelina saharanpuriensis), two nematodes (Ascaridia sp., Procamallanus sp.) and one acanthocephalan (Pallisentis nandai) were found in [21]. This finding is lower than our study as show in Table 1, eight platyhelminthes, six nematodes and three acanthocephalans species were recorded. However, the trematode species are dissimilar and both nematodes and acanthocephalan species are similar with these identified parasites (Table 1).

A number of parasitic fish diseases from different water bodies of Bangladesh have been investigated and, common protozoan parasites such as Trichodina, Chilodonela, Ichthyophthirius, Myxobolus, etc. and metazoan parasites such as Dactylogyrus, Gyrodactylus, Camallanus, Argulus, etc. are infected in most freshwater fishes of Bangladesh [22]. In this research the snake headed fish Channa punctatus was also infected by protozoan Trichodina sp., Chilodonela sp., Ichthyophthirius sp. and metazoan Dactylogyrus sp., Gyrodactylus sp., Camallanus sp.

\subsection{Fish Behavior and Interaction to Habitats}

According to this study, the closed water Channa punctatus were mostly infected by the parasites than the open water fish. The reason may be the closed water habitats cannot move from their living environment to a new environment. They reproduce in same environment and continue their abundances into water. On the other hand, the open water habitats can change their placement with the flow of water from place to place resulting fishes not always infected by the parasites.

\section{Conclusion}

Channa punctatus are mostly infected by protozoa and platyhelminth parasites. Protozoans are the most common parasites that infect gills and skin found in almost all the freshwater fish. Not being exception, five species of protozoan parasites were found in this observation.. Monogeneans were found mainly on skin while digeneans were detected on the gills and intestine. Nematodes and acanthocephalans are intestinal parasites. Acanthocephalans parasitic infestation was poor in Channa punctatus. Arthropods are mostly found on the gills and skin. Rotifer species and Chaetonotus $s p$. are assumed to be new parasite for Channa punctatus which requires detailed micro and macro environmental description. These parasitic groups were not listed in any parasitic study of Channa punctatus before.

\section{Acknowledgements}

We are very grateful to University Center of Shahjalal University of Science and Technology, Sylhet, Bangladesh for funding this study.

\section{REFERENCES}

[1] K. K. Harris, A. K. Gupta, S. M. Agrawal. Pathophysiology of Epizootic Ulcerative Syndrome in Channa punctatus, Journal of Parasitology and Applied Animal Biology, I (2): $125-130,1992$

[2] M. G. Hussain. Freshwater fishes of Bangladesh: Fisheries, biodiversity and habitat, Aquatic Ecosystem Health \& Management, 13(1): 85-93, 2010.

[3] V. A. Doglel, G. K. Petrushevski, Y. I. Polyansky. Parasitology of Fishes, Oliver and Boyd, London, UK, Translated by (Kabata), 1961.

[4] S. J. Srivastava, R. Singh. Seasonal changes in the testes of a freshwater murrel, Channa punctatus, Naturalia, 19: 119-130, 1994.

[5] K. J. Chandra. The anatomy and histology of the alimentary tract of perch, Perca fluviatilis (L.), Progressive Agriculture, 9: 157-62, 1998.

[6] T. Afroz, M. R. Nabi, G. Mustafa. The morphohistology of alimentary canal of Chapila, Gudusia chapra, Bangladesh Journal of Zoology, 27: 51-55, 1999.

[7] A. K. M. Bashirullah. A brief survey of the helminth fauna of certain marine and freshwater fishes of Bangladesh, Bangladesh Journal of Zoology, 1(1): 63-81, 1973.

[8] A. K. M. Bashirullah, A. K. M. Hafizuddin. Two new nematodes (Camallanidae) from freshwater fishes of Bangladesh, Riv. Parassitol, 34: 115-119, 1973.

[9] A. K. Chowdhury. Helminth parasite infestation of histopathological changes in snake-head fishes, M. Sc. Thesis, Department of Zoology, University of Dhaka, Dhaka, 1992.

[10] S. Nahar, H. Khanum, Z. Zaman. Comparative study of parasites of Channa striatus [sic] and Channa marulius in Bangladesh, p. 96, 1993.

[11] M. Banerjee. Studies on Digenean parasites of certain 
freshwater fishes of Mymensingh, MS Thesis, Department of Fisheries Biology and Limnology, Faculty of Fisheries, Bangladesh Agricultural University, Mymensingh, Bangladesh, 92, 1992.

[12] M. J. Alam, M. Rakibuzzaman, M. M. Hasan. Comparative study of endo-parasite infestation in Channa punctatus collected from Hatchery Sewage lagoon, Natural Sciences, 8: 152-156, 2010.

[13] S. Yamaguchi. Systema Hellmouth. Vo-V. Acanthocephala. Interscience. Puble Inc. New York: 36-41, 96-104, 1963.

[14] T. D. Soota. Studies on nematode parasites of Indian vertebrates I. Fishes. Rec. Zool. Surv. India, Misc. Publ., Occas. Pap. No. 54, 1983.

[15] R. M. Cable. An illustrated laboratory manual of Parasitology, Burgess Publishing Company, Minneapolis, 15. Minn. 165, 1958.

[16] Z. Kabata. Parasites and Diseases of Fish Cultured in the Tropics, Taylor and Francis Ltd, 318, 1985.

[17] K. J. Chandra. A Practical Text Book of Fish Parasitology and Health Management, The Bangladesh University Grants Commission, Agargaon, Sher-e-Bangla Nagar, Dhaka, Bangladesh, 213, 2008.

[18] L. Margolis, G. W. Esch, J. C. Holmes, A. M. Kuris, G. A. Schad. The use of Ecological Terms in Parasitology (Report on an ad-hoc Committee of the American Society of Parasitologists), Journal of Parasitology, 68: 131-133, 1982.

[19] A. K. M. Bashirullah, K. M. Elahi. On two new species of Genarchopsis Ozaki 1925 from freshwater fishes of Dacca, Bangladesh, Riv. Parasitol, 33: 277-280, 1972a.

[20] A. K. M. Bashirullah, K. M. Elahi. Three trematodes (Alllocreadiidae) from the freshwater fishes of Dacca, Bangladesh, Norwegian Journal of Zoology, 20: 205-208, 1972b.

[21] M. M. Hasan, M. K. Ahmed, F. Hafiz, A. M. I. Hussain, S. Parveen, S. R. Tinni. Load of heterotrophic and nitrifying bacteria in the sewage lagoon and the receiving river Buriganga, Bangladesh Journal of Microbiology, 23(2): 93-97, 2006.

[22] G. L. Hoffman. Parasites of the Northern American freshwater fishes, University of California Press, Berkeley and Los Angeles, 1967. 